\title{
京都大学増田友也研究室による日本万国博覧会会場計画の検討過程について EXAMINATION PROCESS OF MASTER PLAN OF EXPO'70 DESIGNED BY TOMOYA MASUDA
}

\author{
門 間 光*1, 田路 貴 浩*2
}

\section{Hikaru MOMMA and Takahiro TAJI}

\begin{abstract}
This paper studied 4 drafts of Banpaku-keikaku, which is a master plan of EXPO'70 designed by Tomoya MASUDA \& Associates, and analyses of previous EXPO by them. Because the author aimed to reveal how they developed characteristics and ideas of Banpaku-keikaku.

And the author found following 3 points.

1. Reading and manipulation of the existing topography and "Keikan-ka" did not exist at the preliminary design of Banpaku-Keikaku

2. Masuda's master plan was designed after solving the defects and developing the advantages of previous Expos.

3. Masuda \& associates analyzed previous Expo from the perspective of reading the topography.
\end{abstract}

Keywords : Tomoya MASUDA, EXPO'70, EXPO'64, EXPO'67, Topography

増田友也, 大阪万博, ローザンヌ博覧会, モントリオール万博, トポグラフィー

\section{1. 序論}

京都大学増田友也研究室 (以下、増田研究室) による建築作品の中 で、1970 年日本万国博覧会の会場計画である万博計画（担当 : 加藤 邦男・白井剛・岡崎甚幸 ${ }^{2}$ 、1 1966 年 3 月 10 日設計完了住 2)、以下、完成案と も呼ぶ）は、「景観」と「topography」という増田の思想と関連の深 い概念が設計理念として採り入れられており、思想との関連を探る うえで重要な作品である注 ${ }^{3)}$ 。その万博計画は次の特徵をもつ計画で あった (Fig.1)。すなわち展示ゾーンは敷地の北側に、東から西にテ 一マ館や大広場のあるゾーン I 、外国館等のゾーンII 、民間館のゾ ーンIIIの順に配置され、ゾーンI の大広場を始点として西へと広が る $\mathrm{V}$ 字型の人造湖と一体となり、南東から北西への方向性と会場全 体の見通しをつくることが意図されていた。ゾーンIIII一部は敷地 南北を横断する中央環状線をまたぐ人工地盤とされており、人造湖 と合わせて topograpy (地形) の操作が会場計画の主題である展示館

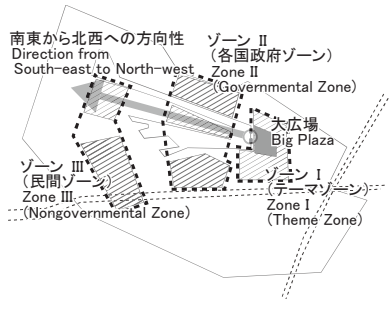

Fig.1-1 Banpaku-keikaku : Placement of exhibition areas(with direction and big plaza)
配置と関連付けられていた。観覧は数箇所ある入場ゲートから座席 付きベルトコンベアに乗り会場内を一巡し全体を概観させて始まる よう設定されていた。そしてこれらの要素によって、会場を「景観 化」すること、すなわち何らかの意味を象徴する状態とすることが 目指されていた。こうした構成は、都心となることが想定されてい た会期後の跡地利用を前提として計画されたものであった。 前稿で明らかになったのは、万博計画に到る簡単な経緯のみであ った。そこで本稿では、その検討過程、特に増田の思想と関連する 設計理念と、先述の計画内容が固まっていく過程を明らかにするこ とを目指す。直接に万博計画の検討過程を示す資料としては、その

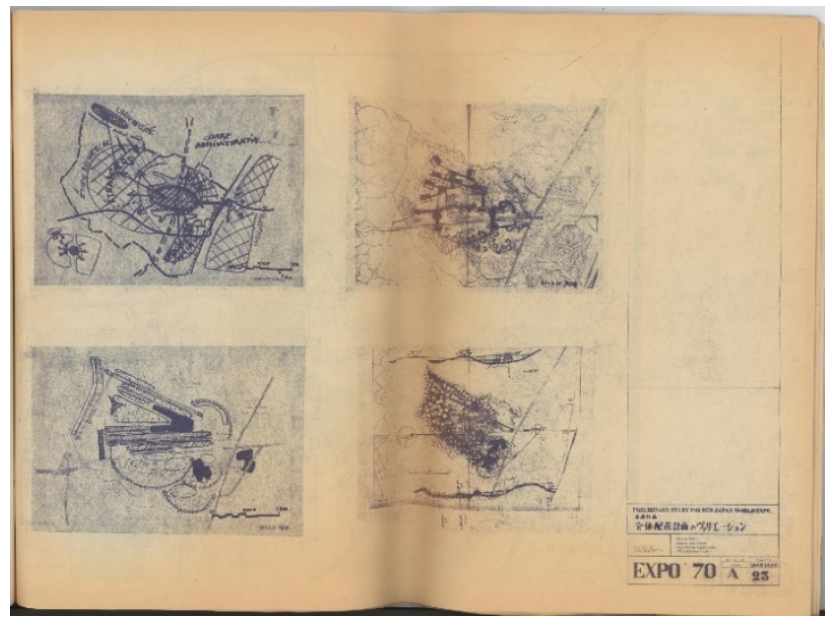

Fig.2 The four drafts of the site plan in 『JEXPO'70 会場計画』
1 京都大学大学院工学研究科 博士後期課程 - 修士 (工学) 京都大学大学院工学研究科 教授・博士 (工学)
Doctoral Candidate, Graduate School of Engineering, Kyoto University, M.Eng. Prof., Graduate School of Engineering, Kyoto University, Dr.Eng. 
草案、および増田研究室による過去の博覧会の会場分析がある。前 者の重要性は明らかであるし、後者には、自身の案の設計につなが る博覧会の会場計画に対する設計者の見解が現れていると考えられ るため、これらを主に用いて研究を進める。

これら資料と分析方法は 2 章または 3 章で詳述するが、草案は万 博計画が収録された青図製本冊子『JEXPO'70 会場計画』のなかに 1 枚の図面「A25 全体配置計画のヴァリエーション」(Fig.2) として 並置された 4 案があり注 ${ }^{4)}$ 、博覧会の分析は万博計画がはじめて発 表された「万博計画 [ I ]」(『近代建築』1966 年 6 月号) に含まれてい る「ローザンヌ博」そして「1967 年カナダ・モントリオール万国博 —EXPO 67一一計画」である。これらの資料の読解及び完成案 との比較検討によって、研究を行なう。なお、草案作成と過去の博 覧会の分析のどちらが先に行なわれたかは不明であり、万博計画の 設計前に行なわれていた博覧会のための基礎調查（1965 年 11 月〜 1966 年 1 月、 1966 年万博計画の主な担当者の中では、加藤、岡崎、白井が 参加梁 5) ${ }^{5}$ と同時期に、加藤はモントリオール万国博の敷地を訪れて いたというが、過去の博覧会の分析の執筆者は署名がなく不明であ る注 6)。増田研究室の万博計画については、筆者による前稿や一連の 発表注 7)、そしてこの論文の母胎となった論文のほかに湦 8)、いまの ところ研究は行われていない。

\section{2. 草案}

万博計画の草案計 4 案は、それぞれ 1 葉の図版であり、そのす心゙ てが先述の図面 A25「全体配置計画のヴァリエーション」という 1 枚の A2 版図面に転写される形で『JEXPO'70 会場計画』に掲載さ れている。いずれの案も線や文字が不明瞭な部分をもち詳細な検討 は難しいため、本稿では大まかな配置構成や交通計画のみを検討の 対象とした。また 4 案の検討には、筆者による描き直し図を用いた。 これは描写の明瞭さが各案で異なり、原図のみでは同列の比較が難 しいためである。そして、施設名等の文字情報が無い場合には、情 報がある案とおおむ称同様の施設、つまり博覧会として重要な展示 館が主に配置されていると判断している。

4 案のうち、 1 案を除きいずれも 1966 年 2 月 15 日の日付が記入 されており、その作成者は、右上案（Fig.5）が岡崎（甚幸）であり、 左下案 (Fig.7) が田中 (喬) であることが、図面中の署名と万博計画 の「共同研究者」もしくは「協力者」から特定できる注9)。残り 2 案 については署名がないもしくは判読不可のため作成者は不明である が、先述の担当者を考慮すると、その作成者は左上案 (Fig.3) につ いてはこの図が描かれる 1 年前までフランスにて都市計画の実務に 携わっていた加藤邦男であり、右下案（Fig.9）はその特徴的な正方 形単位の配置および完成案の担当者でもあることから白井剛である 可能性が高い注 10)。

以下、1 案ずつその会場構成を読み解き、完成案との共通点、特 に 1 章で述べた完成案における「景観化」にまつわる 3 つの特徴、 南東から北西への方向性、展示の全体を概観させる構成、 topography の操作、および跡地利用との関連、について主に検討す る。

\section{2-1. 加藤案}

この案は、破線で敷地境界が描かれた配置図である草案本体と、 その左下にある会場全体の模式図で構成されている (Fig.4)。配置図

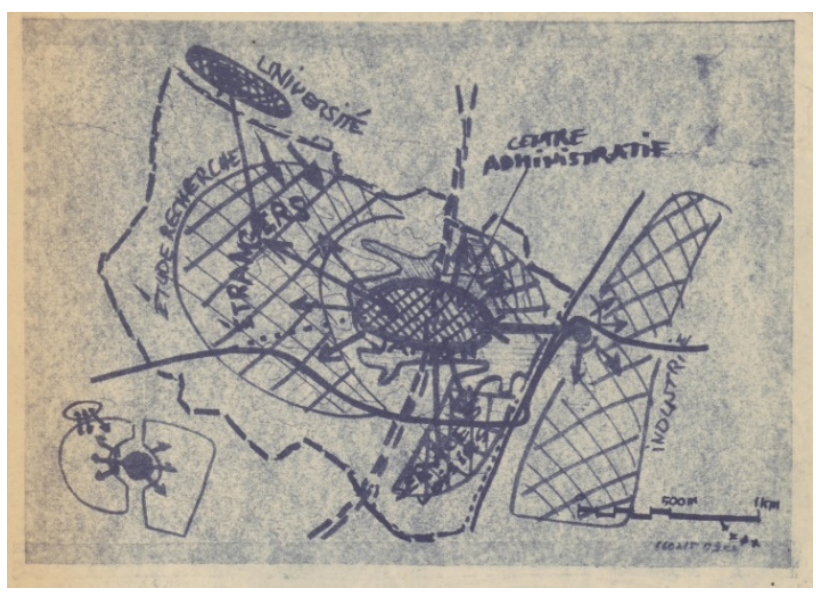

Fig.3 KATO's draft(Original)



Fig.4 KATO's draft(Re-drawn by the author)

にはフランス語で注釈がほぼ完全に付けられており、施設名を概ね 特定できる。この注釈は、同じ位置に 2 種の語句が対応するように 描かれた部分がある。たとえば図左の扇形部分にある「ETUDE RECHERCHE」(研究施設) と「ETRANGERS」(外国) の場合、博 覧会にそぐわない「研究施設」の方は万博終了後の跡地における機 能であり、「外国」は万博の会期中の機能である外国館と解釈できる。

全体配置は模式図から、敷地を東西と中央に三分したものとわか る。その中央に日本館 (JAPON、跡地では CENTRE ADMINISTRATIF つまり行政センター) を配置し、その北東にも何らかの機能が不明な ゾーンが置かれ、また南にはSERVICES LOISIRS サービス施設と 娛楽施設が中央環状線の上におそらく人工地盤として配置されてい る。JAPON ゾーンは、突出部をもつ不定形な輪郭をした人造湖の 中之島になっているが、その左（西）に、扇状に広がった ETRANGERS (外国館) ゾーンが一部は中央環状線をまたいで設定 され、そこは会期終了後は ETUDE RECHERCHE (研究・調查機関) になることが描かれている。のみならず敷地外左上の UNIVERSITE (大学 [大阪大学] ) から研究・調查機関には矢印が伸 ばされており、両者の関係付けが示されている。

敷地外の東にある名神高速道路沿いの南北に長い一帯は 
INDUSTRIE (工業地帯) であり、そこに向かって名神のインターチ エンジと思われる道路の交差部から細い矢印が複数出ており両者の 接続・交通関係が示されている。これには将来の発展をある程度規 定・方向づけする意図があるだろう。インターチェンジから西に進 む矢印や、JAPON ゾーンから ETRANGERS ゾーンへの 4 本の矢 印、もしくは南北に別れたサービス・レジャー施設への 4 本の矢印 がおそらく会場内動線の進行方向を示しており、敷地東端から会場 に入って最初に日本館のある主要なゾーンに入り、その後に外国館 一進んでいく、という会場構成になっている。これに関連して、中 之島中央部の円が動線との対応からおそらく会場内交通機関の駅で あり、東西に伸びる点線がその経路であろう。

会場への交通機関としては、JAPON ゾーンを縦断する二本の点 線がある。これは人造湖という水面の配置と影響関係が見られない ので地下交通経路であり、二種の鉄道路線がともに会場内に乗り入 れることを示しているといえよう。

以上をまとめると次のようになる。敷地全体を中心・西側・東側 という 3 つの地帯に大きく分割し、矢印に示されているように東か ら西といらおおまかな方向性はあるものの、模式図から会場内の観 覧は一方通行的なものではなく、中心からはごこにでも進める自由 度の高いものが設定されていたと考えられる。

この案に特徴的な東から西に向かって徐々に展示ゾーンが広がっ ていく構成は完成案と共通するものである。さらに敷地東を工業地 帯と捉えること、および大阪大学との関連付けは完成案の跡地利用 でも同様に提示されており注 11)、その点で完成案と関係が深い。人 造湖と中之島があり、中央環状線はカーブを描いており南北を分断 する位置にはなく、むしろサービス・レジャー施設と外国館によっ て縦断されており、展示は南北にまたがるよう設定され、そして人 工地盤かトンネルかいずれにせよ topography の操作が行なわれて いる。完成案と異なり、会場内を一周するような交通経路はなく、 また大広場もしくは日本館は人造湖の中にあるためそこから展示全 体を概観させる意図はないようである。そして跡地利用での機能が 指定されているように、跡地との関連付けがここでは試みられてい る。

\section{2-2. 岡崎案}

岡崎案には、図中に文字情報が無いため、以下の施設名はすべて 筆者の推測である (Fig.6) 注 12)。

中央環状線の北側に長方形の大規模展示館および大広場（もしく は日本館）と人造湖、南側にコの字型の小規模展示館、そして敷地 の北西端および南西端に駐車場を配置したものである。敷地の中央 には円状の空中通路がそれら展示館とつながるように配置され、そ の通路は敷地西の駅から敷地東端に近い位置まで東西に伸びる直線 上の経路とも連結している。不定形な灰色部は地上通路であり敷地 東では空中通路と連結され、南側では小規模展示館への経路となっ てもいる。この地上通路は敷地中央部と東端で中央環状線を跨いだ 人工地盤となって、南北を連結している。この案に特徴的な、円形 通路や不定型な地上通路は完成案には存在しないものであり、完成 案との関連はごく少ないといえる。

会場内交通は描かれておらず、また円状通路によって展示を概観 させる意図は無いとはいえないが、会場の全貌を見渡せる位置は特 に設定されていない。中央の円形通路や敷地全体を均等につなぐ地

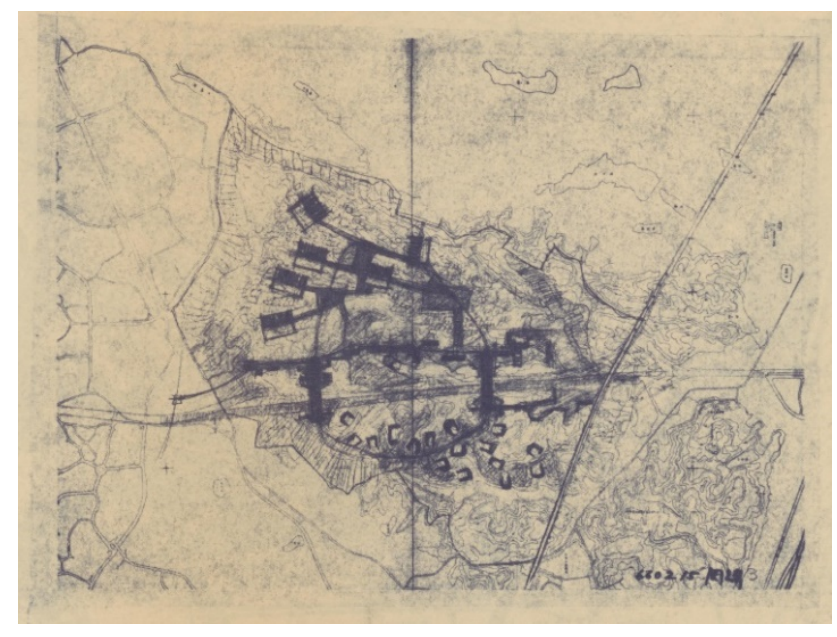

Fig.5 OKAZAKI's draft(Original)

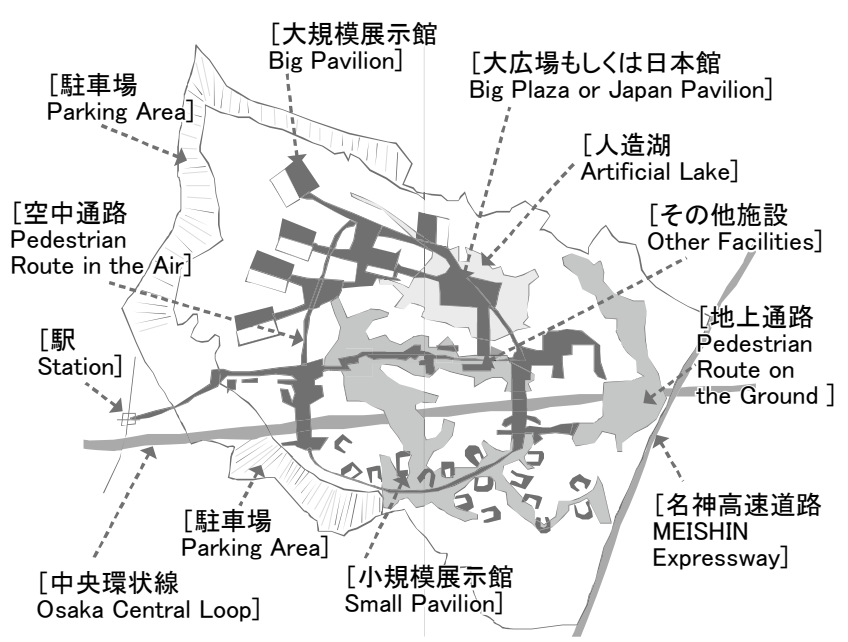

Fig.6 OKAZAKI's draft(Re-drawn by the author)

上通路の配置からわかるように、完成案のような東から西への方向 性は希薄である。とはいえ人工地盤や人造湖といった、完成案と同 様の topography の操作はここでも行なわれている。そして跡地と の関連はこの案には記載されていない。

\section{2-3. 田中案}

この案では図中に施設名等の注橎が部分的に英語で書き込まれて いる注 ${ }^{13)}$ 。全体配置は、中央環状線の北側に展示館等が配置され、 南側は段丘状の広場が 3 つ配置されたものである。駐車場は南側の 東西端に 1 ケ所ずつ設定されている。会場への交通経路としては、 敷地西に駅が描かれている (Fig.8)。

北側では、 $\mathrm{V}$ 字型の人造湖とそれに挟まれた三角形の「 $\square \square \square$ Pedestrian Plaza」歩行者広場が中心にある。そして中央環状線と 平行に、北から「Main Theme」テーマ館、丸（駅）がいくつか水平 に並んだ「Central Trains」中央交通機関、そして「Sub Theme」 サブテーマ館が配置されている。その南のゾーンは注釈が無く詳細 は不明である。人造湖の北東には「Foreign Countries $\square \square \square 」$ 外 国館が弧状に描かれ、同じものが人造湖の北にその輪郭線と平行に 2 ヶ所配置され、さらに敷地北西にも 1 ヶ所配置されている。日本 
館は注釈が無いが、その面積の大きさから、歩行者広場に重なる三 角形の部分もしくはそれと同じ姿で描かれている中央環状線と垂直 に配置された長方形部分であろう。会場内交通は、南側の池のある 段丘に「Pedestrian Ent」歩行者入り口が中央環状線を一部トンネ ルにして配置され、また北側では丸と線で描写されている部分が会 場内交通の駅と経路であろう。

この案に特徴的な $\mathrm{V}$ 字型の人造湖とそこにはさまる島状の地帯、 および人造湖の周囲に整然と並ぶ展示館ゾーン、そして、西端で最 も展示ゾーンが大きくなる配置は完成案にも見られるものであり、 その点では完成案との関連は大きい。南側の段丘エリアについても、 区分位置が異なるが完成案においても既存地形の高低差によって区

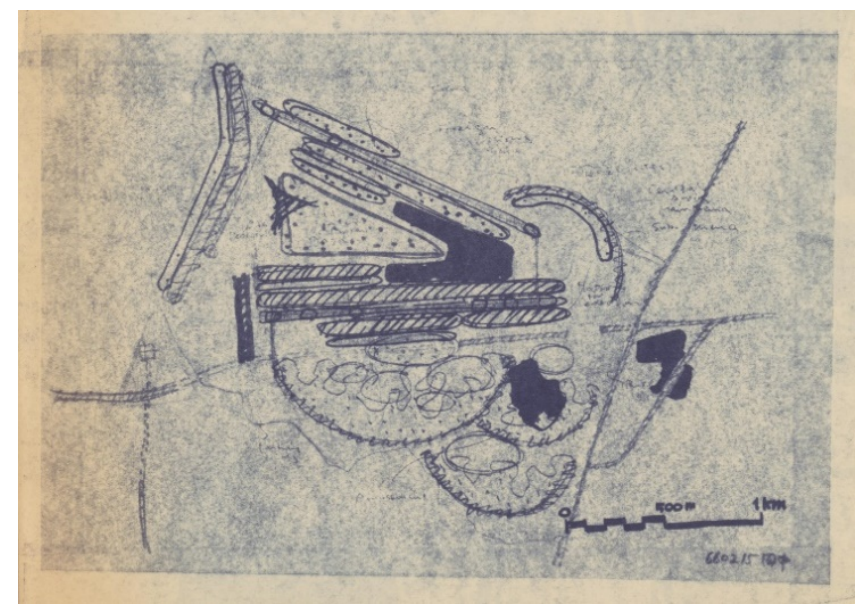

Fig.7 TANAKA's draft(Original)

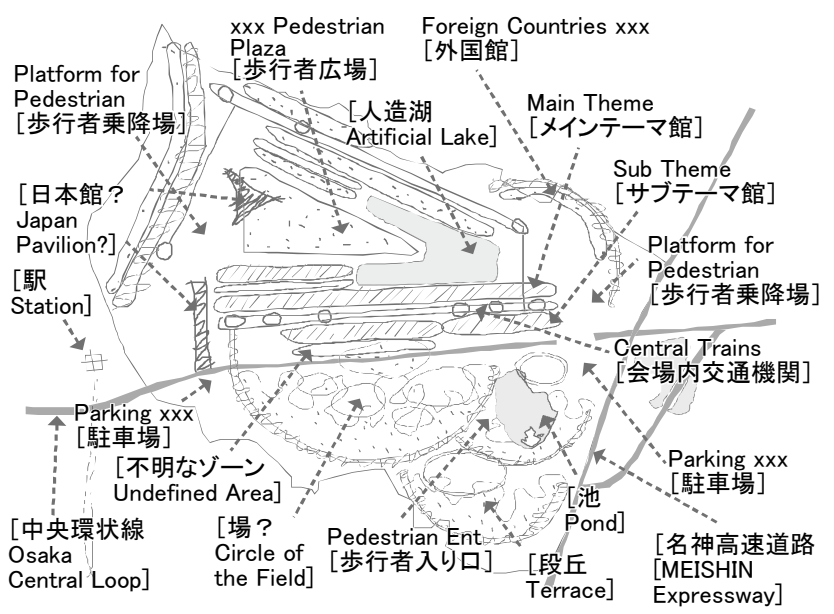

Fig.8 TANAKA's draft(Re-drawn by the author)

分されており注 14$)$ 、共通する手法が完成案でも採用されていたとい える。

敷地東側に歩行者入り口があり、そこから西北に展示館や人造湖 が広がっていく方向性をもつ配置は完成案と共通している。そして 人造湖に加えて歩行者入り口や南側の段丘のような、topography の 操作はここでも行なわれている。会場内交通機関は北側を一周する ように配置されてはいるものの終点と始点のある点で完成案と異な り、また大広場は人造湖に抱かれるような位置にあり、敷地の全貌
を見られる人造湖の東に歩行者降車場があるもののそこには特に施 設は描かれておらず、したがって特定の地点から会場の全貌を概観 させる意図はないようである。さらに、跡地との関連は特に記載さ れていない。

\section{2-4. 白井案}

この案では配置図にくわえて断面図が 2 種描かれており、上の断 面図は下の人工島（人工土地）を拡大したものである（Fig.10）。配置 図には無い注釈が断面図にはあり、断面図の切断位置は不明である ものの、施設名は一部特定できる。

中央環状線の北側に主要施設と人造湖および人工島そして駐車場 が配置され、南側にはその他施設が配置された構成である。人工島

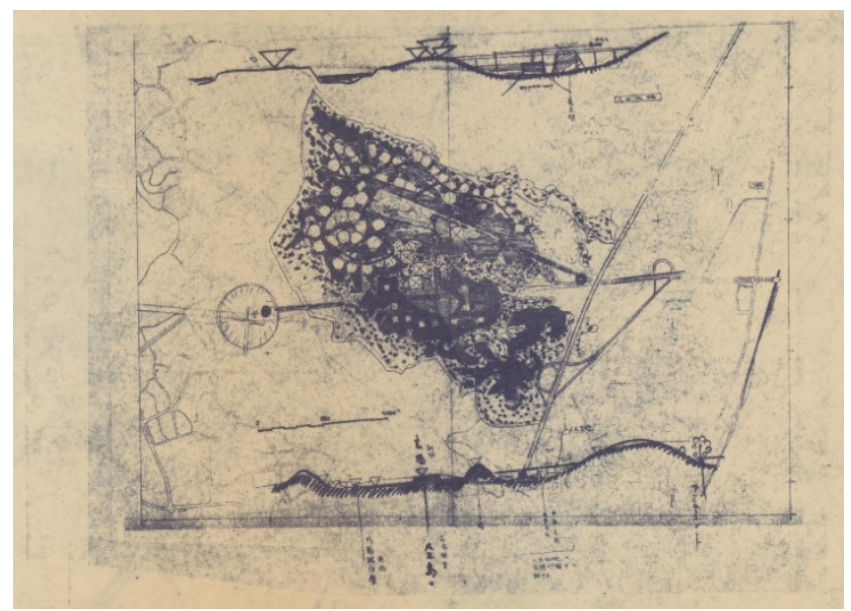

Fig.9 SHIRAl's draft(Original)
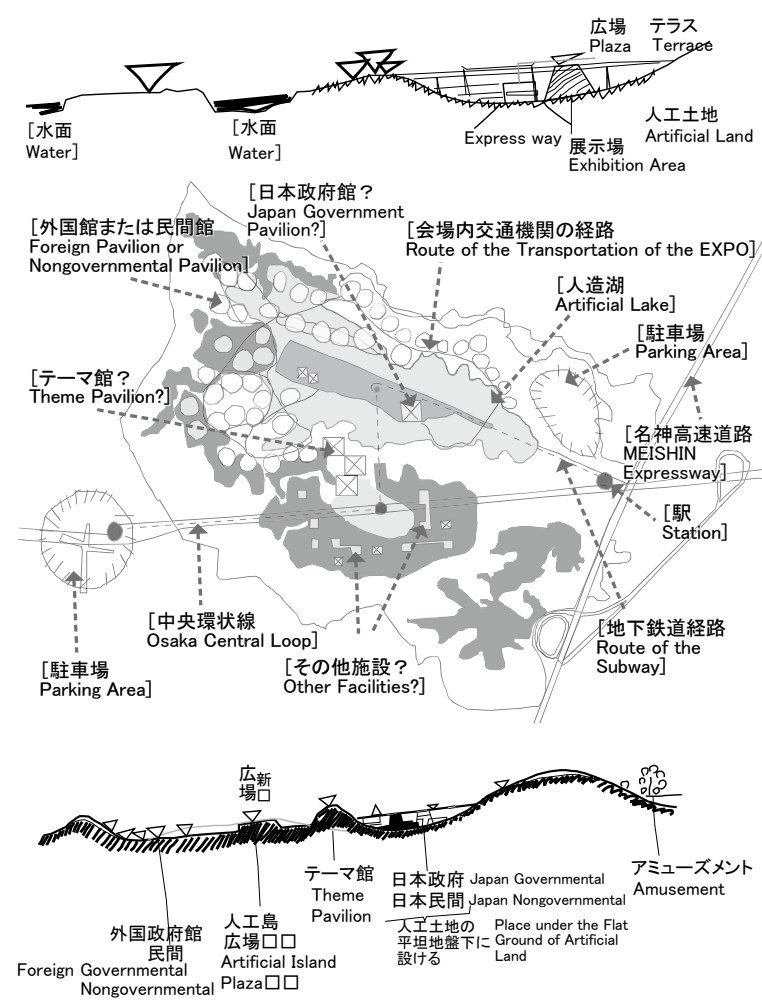

Fig.10 SHIRAl's draft(Re-drawn by the author) 
は池の中に北西から南東に向う長方形に近い形状で配置されており、 そこは南東に日本政府館があり、北西側にまた別の展示館がある。 外国館または民間館は北側に多数配置されており、その間を縫うよ うに会場内交通経路が設定されている。テーマ館は人造湖の南に 3 つ配置されている。そして中央環状線の上に、中央がくり抜かれた ような輪郭をもつ、東西に広がるその他施設が配置された区域があ る。会場への交通経路は、敷地東西端に配置された駅から人工島の 駅一向からような地下鉄道が設定されている。この案に特徵的な、 人工地盤の地上と地下を用いる配置（Fig.10、断面図より）分散配 置された小規模展示館、不定型な緑地帯（もしくは歩行者交通路）とい った要素は完成案には見られないものである。しかし長方形に近い 中之島と結果として $\mathrm{V}$ 字型に近く造形された人造湖は完成案と共 通するものであり、田中案ほどではないが、完成案にも若干引き継 がれた可能性は否定できない。

人工島の形状は南東から北西へと伸びる長方形となっており、東 から西への方向性を多少備えている。会場内交通機関は円形の展示 館に沿う位置にのみ配置されており展示館全域を周回寸るものでは なく、また敷地を全貌できる人造湖の東には駐車場があるものの、 それは南北に大きく広がりその北端からは展示の全体は見られない ため、全体を概観できるようには設定されていないようである。ま たおそらく中央環状線を地下化して南北を連結していること、そし て人造湖と水面および人工土地といった形で完成案と共通する topography の操作はここでも行なわれている。そして跡地との関連 はこの案には設定されていない。

\section{2-5. 小結}

草案 4 案に共通して、人造湖が北側に配置され規模の大きな展示

Table 1 The four drafts and their properties

\begin{tabular}{|l|c|c|c|c|}
\hline & $\begin{array}{l}\text { 南東から北西への } \\
\text { 方向性 } \\
\text { Direction from South- } \\
\text { east to North-west }\end{array}$ & $\begin{array}{l}\text { 展示全体の概観 } \\
\text { Total view }\end{array}$ & $\begin{array}{l}\text { topographyの操作 } \\
\text { Eanipulition }\end{array}$ & $\begin{array}{l}\text { 跡地利用との関連 } \\
\text { topography of the }\end{array}$ \\
$\begin{array}{l}\text { Relations with usage } \\
\text { of the after site }\end{array}$ \\
\hline $\begin{array}{l}\text { 加藤案 } \\
\text { KATO's Draft }\end{array}$ & 0 & - & 0 & 0 \\
\hline $\begin{array}{l}\text { 岡崎案 } \\
\text { OKAZAKI's } \\
\text { Draft }\end{array}$ & - & - & 0 & - \\
\hline $\begin{array}{l}\text { 田中案 } \\
\text { TANAKA's } \\
\text { Draft }\end{array}$ & 0 & - & 0 & - \\
\hline $\begin{array}{l}\text { 白井案 } \\
\text { SHIRAI's Draft }\end{array}$ & 0 & - & 0 & - \\
\hline
\end{tabular}

館もしくは広場と関連付けられており、人工地盤もしくはトンネル によって中央環状線を縦断することが試みられていることから、草 案の時点でも完成案と同様に topography の操作が計画の主題であ る展示館配置と一体に行われていたことがわかった。また、完成案 のような全体の概観は、いずれの案でも意図されていなかった。こ こから、全体を概観する構成は、設計の初期段階では必須とされて いなかったことが推測できる（Table 1)。

南東から北西への方向性については、加藤案と田中案、次いで白 井案に見受けられるが、岡崎案では見られない。また南北への方向 性が意図されていたのは加藤案のみであって、これは完成案におけ るゾーン II の人造湖を挟んだ配置と共通するものである（Fig.1-1）。 のみならず加藤案では他の案と異なり北と南を分断する意図はなく、
むしろ敷地を東西に分割して設計されていた。この東西分割は完成 案には見られないため、草案段階で破萧された手法といえる。そし て完成案のような中之島となっているのは岡崎案をのぞく 3 案であ ったが、中でも完全に島として扱われており周辺と歩行者経路がつ ながっていないのは白井案であった。完成案で設計の前提とされた 跡地利用との関連付けがなされているのは加藤案のみであり、完成 案との配置構成上の共通点が多く見られるのは加藤案と田中案であ った。中でも跡地との関連付け、topography の操作、東南から西北 への方向性という、完成案がもつ特徴を最も多く備えているのは加 藤案であったことがわかった。4 案には展示館のような施設配置の 上でおおまかな共通点しか無いため、設計の初期段階では共通した 基本構想は無く、自由な構想が各人によって行なわれていたのであ ろう。

以上から、完成案の設計には加藤の構想が多く反映されていた可 能性が高い。では「景観化」についてはどうだろうか。加藤案は、 中之島が観覽の中心となっており、その上下に展示ゾーン、東に大 広場を付け加えれば完成案に近付く。しかし、中之島の東に施設が 配置されており、中之島から全体を概観する意図は薄い。したがっ てこの時点では、全体を「景観化」するという理念、全体を一望さ せることで観覧者に会場を把握させるのみならず、博覧会という概 念までをも理解させようとしていた理念は、設計に取り込まれてい なかったのであろう。つまり「景観化」は、この草案の作成後に明 確化され、それを具現化する形で完成案のように人造湖の東に大広 場という博覧会の始点であり博覧会を捉える視点でもあった施設が 配置されたのではないだろうか。こうした設計過程は、本稿で扱っ ている完成案の修正案が掲載された「万博計画 [ II]」で述べられる、 与件と計画内容との動的収斂そのものである注 ${ }^{15)}$

\section{3.「万博計画 [ I ]」における過去の博覧会の検討}

「万博計画 $[\mathrm{I}] 」 に は 、 「 日$ 本万博」と題された設計理念から具体 的な計画内容までを含む彼らの会場計画の全容の他に、「ローザンヌ 博」そして「1967 年カナダ・モントリオール万国博—EXPO 67 ——計画」というふたつの博覧会の会場計画の分析が、記事全体 の三分の一を占めている。つまり過去の博覧会の分析が記事中で大 きな意味をもっているのである。したがってここでは、ふたつの博 覧会の分析が、増田案にどのように活かされたのかを考察する。

3-1. ローザンヌ博（1964）

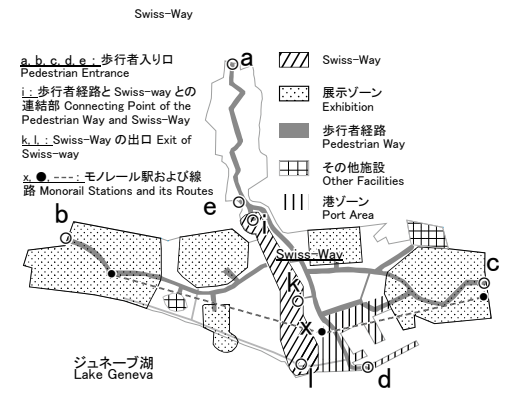

Fig.11-1 Analysis of the master plan of Lausanne EXPO(Re-dawn by the author)



Fig.11-2 Site map of "Swiss-way" 
ローザンヌ博とは、1964 年にスイスのローザンヌにて行われたス イス連邦博覧会である。分析は $1 . 「 1964$ 年 ローザンヌ、スイス連 邦博覧会の検討」、2.「敷地と境界」、3.「Zone のいろいろ」、4.「各 種 Zone の連結」、5.「結論」の順に計 5 節（節番号は筆者が便宜的 に付けたもの）で構成された、計 3 ページのものである。1 と 2 節 は会場計画の前提条件の説明であり、3と 4 節はこのローザンヌ博 の主題の一つとされた"Swiss-Way"、これはway と銘打っているが 基本的に建物（黒部）の連なりである、の会場計画における働きを 主に巡回計画の観点から分析している。各節の概要は次の通りであ る (Fig.11-1)。

1.「1964 年 ローザンヌ、スイス連邦博覧会の検討」：物品展示 の問題と展示館の道順の問題はすべての博覧会に共通する。この問 題の解決に非常に成功したと言われるローザンヌ博における方法、 特にその主題の一つである"Swiss-Way"についてその全体配置にお ける役割と、全体の巡回計画を検討することは今回の大阪万博のた めに意義があるだろう。

2.「敷地と境界」: 敷地の南はジュネーブ湖に、北は東西に走る高 速道路とロータリー（e 周辺、その東西に道路が走る）で限定されてい る。ロータリーから北に延びる小さな敷地もあるが、展示館は主に ロータリーの南側に配置されている。会場への入口は敷地末端にそ れぞれ備えられている $(\mathrm{b}, \mathrm{c}, \mathrm{d})$ 。

3.「Zoneのいろいろ」：敷地は、主に三つのゾーン、（1）「博覧会 全体の導入と総括としての一般的Zone。特殊ゾーンに展開されるさ まざまな主題の要約（いわゆる Swiss-Way）」（i と k と l のある斜線 部、[筆者注 : Swiss-Way では $\mathrm{K}$ 点の周辺にある広場から東西に抜けられそ うだが、左側は緑地でありそれは不可能のようである（Fig.11-2）]）、（2） 「様々な展示がなされる特殊 Zone」(図中の網点部)、（3）「レストラ ンと遊戯施設をもったリクリエーション・ゾーン (港)」(図中の縦線 部）によって構成されている。

4.「各種Zone の連結」:この節にのみ小見出しが付けられている。 前提として、Swiss-Way はその性質上北から南への一方通行である。 まず「(a) 一般 Zone へのアプローチ」ではb もしくは c から徒歩 で i に行くアプローチには導入空間も心理的な準備もなく成功して いないことが述べられる。「(b) 一般 Zone からの退場」では、SwissWayには出口が少なく（kとlのみ）、結果として Swiss-Way が他の Zone とあまり関係づけられず独立しているように感じられると説 明される。そして「(c) 各種 Zone の連結」では、Swiss-Way が会 場の東と西を心理的に分断しており、特殊 Zone に対する「アンテ イ・テーゼ」であり、あるべき「ジン・テーゼ」（総合）ではないの が、最も大きな問題点であり疑問点であると述べられる。

5.「結論」:「主要な巡回路のシステムは、一般ゾーン [Swiss-Way のことと特殊ゾーンとの区別をきわだたせているゾーニングのシ ステムと、うまく対応していない。一般ゾーンは、観覧者のさまざ まの巡回ルートのすべてとは適切に融合しておらず、しかも、特殊 ゾーン相互間の連絡をむしろ遮断するように、配置されている。と 述べられる。

以上、ローザンヌ博の分析では巡回路とゾーニングの不一致とい う問題点が指摘されており、その点でこの博覧会は悪例として捉え られていたのであった。そして、この分析に明らかなように、増田 案の特徴であった topography の操作や洞察そしてそれによる会場
内を概観させるための配置構成や交通機関の設定は、ローザンヌ博 には見られないものであった。なお跡地についてはこの記事では全 く言及がない。ここで増田案をいま一度眺めると、次のことがわか る。

増田案では高さが無く Swiss-way よりも心理的な隔離が弱い水 面によってゾーンが区分されている。さらにもっとも大きな心理的 な壁といえる中央環状線に対し、小さなトンネルではなく比較的大 きい人工地盤をその上に設けることで遮蔽感を減少させている (Fig.1-1)。そして観覧の心理的な準備として、入場後にまず交通機 関で会場内を一巡するよう設定されている（Fig.1-2）。ほかに、大広 場からの見通しやそれを強調するための人造湖の配置等、会場の把 握を考慮した設計が随所にある。つまり、ローザンヌ博の問題点の 多くは増田案では解決されており、その検討は自身の案のための批 判的検討であったといえる。

\section{3-2. モントリオール博 (1967)}

「1967 年カナダ・モントリオール万国博—EXPO 67一一計 画」ではカナダ、ケベック州モントリオール市で行われる予定で工 事が進んでいた 1967 年万国博覧会の会場計画が検討されている。 記事は 1. [標題のない序説]、2.「地理学的環境」、3.「都市的環境」、 4.「会場計画」の計 4 節（節番号は筆者が便宜的に付けたもの）で構成さ れた、計 6 ページのものである。1 1 から 3 節が会場計画の前提的条 件の説明であり、4 節がそれらを踏まえた会場計画の分析である。 各節の要点は次の通りである（Fig.12,Fig13）。

1. [標題のない序説]:「建築計画の技術的な面」に限って、モン トリオール博を分析して、それが「我々の 1970 年日本万国博覧会 会場計画案作成の貴重な資料となった」。

2.「地理学的環境」：モントリオール市は、北をプレリ河、南をサ ン・ローラン河に囲われた島に位置しており、モン・ロワイヤルと いう市のシンボル的存在の丘陵とサン・ローラン河の間に市の発祥 当時から現在まで中心市街地がある。そして、サン・ローラン河と 平行して南北に走るシェルブルック通りとモン・ロワイヤルの北を 東西にサン・ローラン河からプレリ河に到るサン・ローラン通り近 辺が市の「発展軸」であり、そのサン・ローラン通りの河への突き 当りがモントリオール港となっている。万博の敷地（横線部）は、

「これら都心地区、港地区を向いにしたサン・ローラン河の中之島 サン・テレーヌ島［イール・サン・テレーヌ］を中心にして護岸造 成した埋立地である。」

3.「都市的環境」: モントリオール島は人口約 100 万人の広大な都 市圏が先述の一つの都心に依存している。サン・ローラン河に面し たマッケイ埠頭を含む地区 (網点部) は流通施設が多く工業的性格で ある。

4.「会場計画」:この節のみ小見出しが付けられている。

1）空間的検討（Fig.12）: 会場は主に 4 つに区分され、そのうち 展示ゾーンはマッケイ埠頭、イール・ヴェルト、イール・ノートル ダムの 3 つの区域にある。

2）時間的検討（Fig.13）：会場内交通には、高速で長い距離を連 絡する A システムの EXPO・EXPRESS と、その他ミニレールなど の $\mathrm{B}$ システムの二種が設定されている。

3）入場者の検討 : 延入場者数や一日当り入場者数が説明され、ま た入場者の時間的配分と展示館面積が概ね比例していると指摘され 


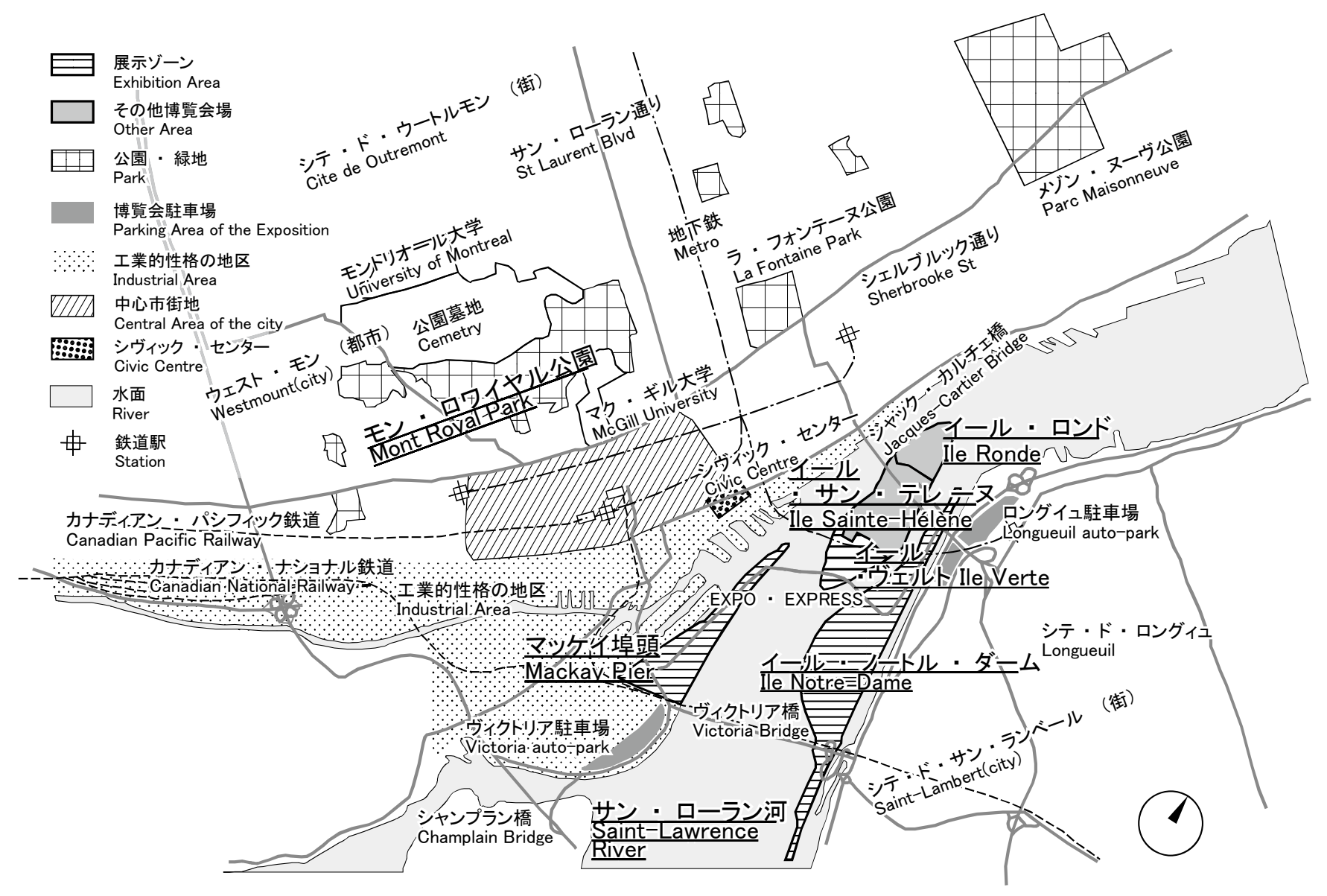

Fig.12 Map of Montreal and the site of the Montreal EXPO(Re-drawn by the author)

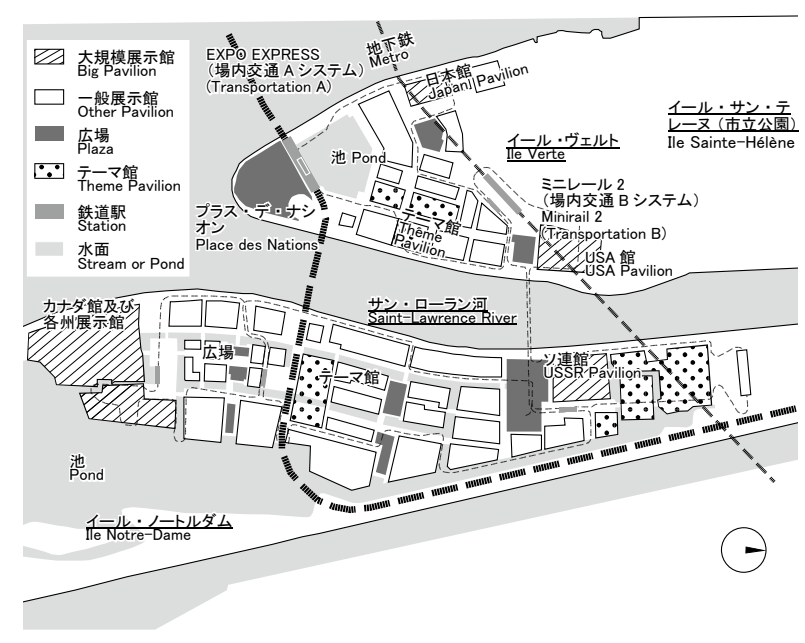

Fig.13 Site map of lle Verte and lle Notre-Dame(Re-drawn by the author)

ている。

4）会場の質的空間の検討（Fig.13）：博覧会のメインテーマから うまれるサブテーマを、3 つの展示ゾーンにひとつずつ配置された テーマ館（網点部）でそれぞれ展示し、「創造者としての人間」とい うサブテーマについては 3 つの展示ゾーンに分散して配置する。テ 一マ館のあるゾーンは各地区の中心にあり、入場者はまずそこを通 るように設定されており、なおかつテーマ館の地上階はピロティと
され通行が自由である。飲食店等のサービスゾーンも会場全体の中 で空間構成上の機能、たとえば広場として周辺ゾーンを連結すると いった機能が設定されていて、さらに「町の「地図」をよみとらせ る一つの記号的役割」を果たしてもいる。各地区の中心は都市的風 景として構成され、庭園や緑地とは離れて配置されている。それだ けでなく、大きい展示館（斜線部）は各地区の端に、小さい展示館 はまとめて地区の中央に配置するといった展示館配置の濃淡をつく らないようにする工夫があり、主要な展示館は広場等から見通せる ように設定されてもいる。

5）デザイン規制：イール・ノートルダム地区は、その「運河の造 成や大テラスの造成」が「強い表現力をもつ建築的空間であり、そ の上に後からくる建築に左右される以前に会場に一つの統一感を打 出している様である」という。そして、その他会場全体の統一のた めのデザイン規制が、建築そのものや照明さらに看板に至るまで設 定されている。

以上の増田らによる分析をふまえて、増田案とモントリオール博 の地理的環境の活用方法を比較すると、モントリオール博では敷地 は 3 つの島もしくは埠頭に区分されていたが、増田案はそこにさら に 3 つの島 (点線部) が足されたものと解釈できる (Fig.14)。両案は どちらも中之島と水面を含むが、その働きが全く異なり、モントリ オール博での水面（サン・ローラン河）は所与の地形的特徴に過ぎ ず会場構成に積極的に働いていない空洞に近く、会場の中心がその 空洞であり敷地全体に方向性は薄い。しかし増田案では中之島を配 
置することによって会場全体の配置的中心を中之島の展示ゾーンと し、なおかつ敷地全体に展示の序列と対応寸る方向性を作り出して いる。つまり、陸地と水面のより積極的な関連付けが、増田案では 試みられたといえる (Fig.1-1)。さらに、3つの島に同じテーマをも つゾーンを分散させる会場構成 (増田案のゾーン II)、水面を活用した topography の操作による敷地造形、くわえてまず展示の中心を概観 させる会場内交通計画の一部分が、増田研究室の万博計画と共通し ている。しかしモントリオール博では、増田案の大広場のように全 体を概観させる特定の施設や地点はないようである。

つまり万博計画の、巨大な人造湖によって展示ゾーンを分割しな がら序列づけ、なおかつ会場内に見通しを設けることによりテーマ を適切に理解させるという基本的構想は、実際の博覧会でも用いら れる予定の現実的な方法だったのである。そう考えるとモントリオ ール万博の分析は参考にしたことを示すのみならず、自らの計画案 の妥当性・実現可能性を示寸意図もあったのではないだろうか。

\section{3-3. 小結}

まず、ローザンヌ博は増田案と共通点が少なく、モントリオール 博は増田案といくつか共通点をもつことがわかった。そして、前者 は悪例として、後者は好例として捉えられていた。

ローザンヌ博の検討では、博覧会として瑕疵となり得る要素がい くつか数多く指摘されていた。そうした要素は増田案には存在しな いものであり、したがってローザンヌ博の検討は自身の案をより適 切なものにするための批判的な検討であったことがわかった。増田 案との比較で特筆す心゙きなのは、ローザンヌ博において意味的・配 置的中心に設定されていた Swiss-Way が博覧会の総合になってい ないという指摘であろう。増田案では、人造湖東の大広場とテーマ 館を含むゾーン I が、博覧会の一般的テーマを扱うという SwissWay に近い性質をもちながらも、視覚的に北側全体を総合する、ま さに博覧会を象徴する施設として設計されていたのである。つまり 増田案でのゾーン I は博覧会の全貌を視覚的にも展示の上でも総合 し概観させることが明瞭に意図されていた。このように、ローザン 又博の欠点は、増田案では単に解消されていたというょりも、より 適切な形をとって全体構成を総合するための一部分として積極的に 解決されていたのであった。

モントリオール博の検討では、その会場計画はローザンヌ博に比 して積極的に評価され批判はほとんど行なわれていなかった。そし て、同じテーマのゾーンを分散配置するといったような、増田案と 共通する要素がいくつか存在していた。増田案との比較で特筆す心゙
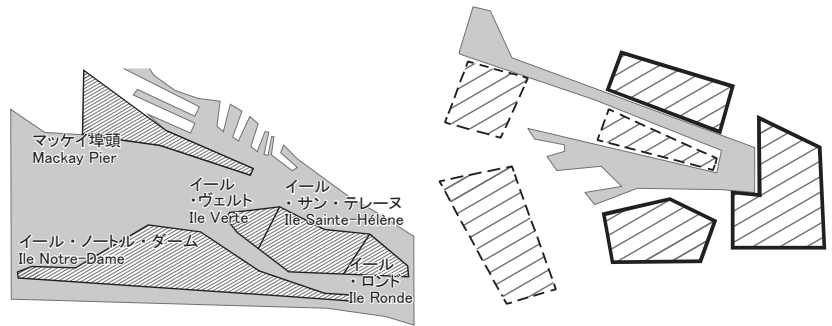

Fig.14 Comparison of the usage of the topography(left : Montreal Expo, right : Masuda's plan)
きなのは、モントリオールにおける運河や「大テラス」の造成が「強 い表現力をもつ建築的空間」であると説明されていたように、川と 島という会場の地形的 (topographic) 立地条件から来る会場構成の利 点が指摘されていたことである。増田案の人造湖と中之島ふくむゾ ーンII の構成では、モントリオールのように所与の条件として建築 空間の造形に活用するにとどまらず、自らの「景観化」という理念 を視覚的に具現化するための必須の要素として、そこに新たな地形 的状況、つまり島 (陸地) と川という高低差とそれにともなう視覚的 見通しを造り出していた。このように、モントリオール博で評価さ れていた要素は、増田案では活用されるにとどまらず理念や配置構 成といった会場計画の基底として無くてはならない要素へと発展さ れていたのであった。

\section{4. 結論}

まず草案の分析から、完成案のもつ 4 つの特徵のうち跡地との関 連付けを意図していたものは加藤案のみであったことがわかった。 さらに万博計画の検討過程では、4 者による草案作成によって複数 の要素が検討されその一部、主に加藤のアイデアは完成案にも多く 採用されていたことがわかった。加藤案は完成案に近い東から西と いう方向性や周囲との関係付をもち、なおかつ基本的な配置構成が 完成案と類似していた。田中案も人造湖の形状や西に向かって拡大 する展示ゾーン等主要な配置構成の点で完成案と共通点があった。 したがってこの 2 案が完成案の雛形として扱われていた可能性が指 摘できる。さらに人造湖や人工地盤等の topography の洞察と操作 にまつわる完成案のもっていた特徴の多くは複数の草案に存在して おり、つまり草案の段階で既に構想されていたこともわかった。と はいえそうした地形の設計は敷地が備えていた高低差の豊富な丘陵 地という条件を活用したものであって、完成案で説明される topography の操作と洞察やそれに伴なう三次元的・建築的な地形の 設計は、この段階では構想されていなかったのではないか。そして 設計を統御する基本的な理念、特に「景観化」は、草案作成という 設計の初期段階では現れておらず、完成案に進んでいく過程で設計 に取り入れられた可能性が指摘できた。

過去の博覧会の検討と増田案との関連については 3 章で概ね明ら かになった。ここではそれを基に、増田の思想および万博計画にお ける計画理念との関連で以下の 2 点を特筆しておこう。第一に、口 ーザンヌ博を分析し発見した問題点を自身の案では人造湖と陸地の 関係という topography の操作に含めながら解決していること。第 二に、モントリオール博における既成の topography の利用を評価 しつつもそれを単に模倣するのではなく、展示館の配置構成という 博覧会会場計画において主眼とされる要素と島と人造湖という topography とを密接に結びつけながら発展的に活用し、さらにその 活用によってテーマを入場者に「見せる」ということを第一の目的 とした「景観化」という計画理念を具現化・可視化した点である注 ${ }^{16)}$ 。 したがってこれら過去の博覧会の分析は、topography の操作と洞察 という増田の思想に根をもつ計画理念をもとに行われたものであっ たことが指摘できる。

ここで、万博計画の計画理念に述べられている資料を読み取る際 の志向の重要性、「もっとも重要なことは、設計者には既にして用意 された志向があり、その志向に即して諸資料がそれぞれの表情をも 
つという心理学的事実である」注 1)7 と、ローザンヌ、モントリオー ル両博覧会の検討とのつながりも明らかになった。たとえばまず会 場を概観させるべきといった博覧会の会場計画のあるべき姿をあら かじめ「志向」しながら、博覧会の会場計画という資料の「表情」 を、たとえば主に Swiss-Way の役割を巡回路の観点から分析する といったように読み取って検討が行われていたのである。

万博計画の基本的構想にあったこうした「志向」は、増田ではな く加藤によるものであろう。というのも、加藤は万博計画の設計前 に都市計画の実務経験をフランスで 5 年ほじ積んでおり注 ${ }^{18)}$ 、その 一部は実施されてもいる注 19)。さらに加藤は彼の地で行なわれてい た都市計画にも批判的でありその現実的な理想形を追い求めていた からである注 20)。こうした加藤の志向が、topography という概念を いかにして設計と関連付けるかという、博覧会という機能種別にと らわれない増田の動機によって規定され、設計されたのが万博計画 だったのであろう注 21 。

以上、設計過程と計画内容が固まっていく過程の一部が、次のよ うに明らかになった。まず理念に関していえば、topography の洞察 と操作は、草案の段階ではあまり重視されてはおらず、過去の博覧 会の分析では、既にその理念に則って分析が行なわれていたことが わかった。ここから、過去の博覧会の分析は草案作成後に行われた こと、および草案作成後にこの理念が設計において重視されるよう になったことが指摘できる。「景観化」については、草案の段階では 全体を概観する配置が行なわれていないことがまず明らかになった。 そして過去の博覧会の分析では全体を概観することの重要性や博覧 会の総合になっていないことへの指摘があり、意味を象徴するかど うかについては特に言及がないものの、そこでは既に「景観化」に 近い理念を基に分析が行なわれていたことがわかった。つまり景観 化は設計前には定められておらず、完成案の設計が始まったあとに 設計方針として組み入れられたのであろう。くわえて草案 4 案に配 置構成上の共通点が少ないことと合わせて考えると、設計の初期段 階では増田の関与や設計理念および計画内容における指針の統一は ほとんどなかったといえる。

計画内容についていえば、草案の段階でも人造湖と中之島はす心゙ ての案に存在しており、田中案では完成案のようにV字型でもある。 しかしいずれの案でも完成案のような「景観化」を実現していた眺 望 $\left(\right.$ パースペクティヴ注 ${ }^{22}$ ) $)$ をつくる意図は無かった。したがって 大広場と人造湖と展示館のある陸地によって全体を構成しなおかつ 概観させるという増田案の特徵は完成案の設計が進むなかで生れた ものであることがわかった。これが加藤の構想なのか増田の構想な のかは不明である。いずれにせよ、大広場から全体の見通しをつく るという会場把握にとっての利点を生む北側の展示ゾーンの配置構 成に、何事かの理念（主に博覧会のテーマ）を伝達するという博覧 会の最も重要な役割が与えられていたのであり、それがその時点で 既に増田研究室で追求されていた「景観化」の適用による解決とし て提示されていたのが万博計画だったことに疑いはない注 23)。

\section{注}

注1）『増田友也先生退官記念 著作 - 作品目録』、京都大学工学部建築系教 室増田研究室記念事業会, 1978.3、pp.8-9

注2）万博計画がまとめられた青図製本冊子『JEXPO'70 会場計画』は、主 に 1966 年 3 月 10 日付の案で構成されている。この資料は増田友也建
築設計関係資料として保管されている。

注3）門間光・田路貴浩「京都大学増田友也研究室による日本万国博覧会会場 計画 (1966) の特徴 西山外三もしくは丹下健三による会場計画との比 較を通して」（『日本建築学会計画系論文集』Vol.85,No.768,2020 年 2 月号)

注4）これらは「ヴァリエーション」と題されているが、後述するように完成 案より一ヶ月ほど古い作成日時であるため、完成案の変種というより完 成案のための草案ととらえる方が妥当であろう。

注5）『'70 日本万国博覧会会場計画に関寸る基礎調査研究 京都大学万国博 調査グループ報告書』（京都大学万国博調査グループ、財団法人日本万 国博覧会協会、1966 年 2 月）、p.1-1 およびp.1-2の「まえがき」より。 この書籍では頁数は 1-2 のように章毎にふられている。

注6） 2017 年 10 月 13 日に加藤邦男より聴取。

注7）筆者による一連の発表には以下のものがある。門間光・田路貴浩「京都 大学増田友也研究室による日本万国博覧会会場計画 (1966) の草案につ いて」（『日本建築学会大会学術講演梗概集（東北）2018 年 9 月』、 2018、pp.261-262)、門間光・田路貴浩「京都大学増田友也研究室によ る日本万国博覧会会場計画（1966）における人造湖の意図」（『日本建 築学会近畿支部研究報告集計画系』、第 58 巻、2018、pp.601-604)、 門間光・田路貴浩「京都大学増田友也研究室による日本万国博覧会会場 計画（1966）の概要と特徵」（『日本建築学会近畿支部研究報告集 計 画系 』、第 59 巻、2019、pp.549-552)

注8）「京都大学増田友也研究室による日本万国博覧会会場計画の成立の背 景」、『建築論研究』第 2 号、2020、pp.44-54

注9)「万博計画 [ I ] 」、p.32

注10) 田中の草案があることから、先の 3 名以外の万博計画に関わった者の作 成である可能性もあるが、加藤については岡崎によって主担当と言われ ていること $(2018$ 年 1 月 17 日聴取、「京都大学増田友也研究室による 日本万国博覧会会場計画 (1966) の特徴 西山外三もしくは丹下健三に よる会場計画との比較を通して」の注 2 における聴取日時「2017 年 1 月 17 日」は「 2018 年 1 月 17 日」の誤りである)、白井については過 去の国立劇場計画（門間光・田路貴浩「京都大学増田友也研究室による 国立劇場計画 (1963) の「景観」」、『日本建築学会大会学術講演梗概 集（関東） 2020 年 9 月』、pp.221-222）等の他の担当作品に頻出する 正方形単位をここでも用いていることから、そのように判断した。

注11) 図面 A24「跡地と周辺」、『JEXPO'70 会場計画』では、「阪大工学部」 と万博敷地とが関連付けられ、両者は「敷地周辺一体の公共施設ゾーン」 として設定されている。

注12) 以下の岡崎案の記述では、規模の大きい施設もしくは数の多い施設は博 覧会にとって重要な施設、寸なわち展示館ととらえている。敷地北西と 南西にある直線が多数引かれた部分は法面の表示とも捉えられる。その 場合大規模展示館から西方向への視線が開けることになるが、南西の法 面については展示館や通路と特に関連付けられていないため、こちらは 法面ではない可能性が高い。したがって両者とも法面ではなく、博覧会 に必須の駐車場と捉えている。

注13) 田中案の英語の注棌は、かすれた筆記体で判読が難しく、Pedestrian と している部分は実際には P と an 程度しか読めない部分もあるが、反対 に Pedestrian とはっきり読める部分もあり、文字の数が両者で同一で あることからどちらも Pedestrian としている。他の注釈も読みづらい ものがほとんどだが、博覧会の機能を考えると今回図示しているもので 間違いないだろう。

注14) 図面 $\mathrm{A} 20$ 「主要諸施設と恒久施設及び仮設施設」と図面 $\mathrm{A} 11$ 「地形と勾 配分布」（どちらも『JEXPO'70 会場計画』より）を見ると、敷地南の LOGEXPO (宿泊施設) ゾーン付近は谷に配置された道路によって区分 されていることがわかる。

注15) 記事全体は「京大建築学教室・意匠研究室」つまり増田研究室の署名で 『近代建築』1966 年 7 月号、pp.29-56 に掲載されている。特に「序・ Topography と建築的計画」（pp.30-31）において、topography という 与件と設計される空間像との関連が次のように述べられる。「トポグラ フィは志向的空間イメージをとらえる過程で積極的に働くものである。 換言すれば、空間像はトポグラフィの操作に於てその成立の契機をうる ものであり、その成立が、またトポグラフィの操作に逆に返って作用し て、以後の把握を方向つけ、暫時限定して来よう。いづれにしても、ト ポグラフィの操作にかかわるこの動的な収斂過程そのものが、建築的計 画における主要な作業のひとつであり、」、p.30。

注16)「万国博覧会は、言わばテーマ博覧会とも言うことができ、入場者にテ 
一マをいかにく見せる $>$ 一 donner à voir一一かと言うことが第一の 目的である。」、『JEXPO'70 会場計画』、p.4。詳細は門間光・田路貴 浩「京都大学増田友也研究室による日本万国博覧会会場計画（1966）の 特徵 西山外三もしくは丹下健三による会場計画との比較を通して」を 参照のこと。

注17)『JEXPO'70 会場計画』、p.1、さらに「資料が、表情をもって設計者の 志向の向うに現われる。設計者は、その表情的価值によって資料を選び、 構造化する。それ故に無限の資料が在るのではなく、志向において限定 されたいくつかの資料があるにすぎない。本提案の資料的処理において、 このことが明らかにされるであろう。」とも同ページで説明されている。 注18) 増田友也建築設計関係資料に所蔵の、加藤邦男自筆の履歴書より。

注19)フランス、マルチーグ市に対する開発計画は、加藤が主担当であり実施 された。加藤邦男『フランスの都市計画』、鹿島研究所出版会、1965、 pp. $141-180$

注20)「都市計画に関する雑誌が、常に同じ大袈乷な身振りと宣言文に終始す る域を脱せず、他方建築家の視野は比較的せまい造形的な範囲に限られ ている。本当の意味で、都市を創造すべき都市デザイナーも、土地のう えで実際に仕事のできる都市計画家も非常に稀である。」、『フランス の都市計画』、p.96、また、pp.113-114のサルセルの計画への批判では、 「都市計画的配慮のあらゆる欠点」、「わびしさを市民に感じさせる」 とまで言われている。

注21)『加藤邦男 +京都大学建築学教室加藤研究室 建築作品資料集』（加藤 研究室資料編纂委員会、2018) では万博計画は加藤の作品として掲載さ れている。しかし本文で述べたように、万博計画は加藤の作品ではなく 増田研究室の作品といえる。

注22)「テーマ・ゾーン：万国博覧会の主行事や科学の様々な新しい可能性を 実験体に示す 2 万人収容の大広場を中心に構成される。地形上の利点と して人造湖にそったパースペクティヴにより会場全体が見透される。」、 『JEXPO'70 会場計画』、p.19

注23)「景観」もしくはほぼ同じ意味をもつ「風景」が設計説明において提示 されている作品には、鳴門市立工業高等学校 (1963)、国立劇場 (1963)、 京都府立高等学校 (1963)、双ヶ岡環境工学研究所 (1966) などがある。 双ヶ岡環境工学研究所は京都大学建築学教室・意匠研究室「共同研究 : 歴史的環境の保存と開発(ケーススタディ)」、『近代建築』1966 年 5 月 号、pp.33-58 より、その他は増田友也建築設計関係資料に所蔵の各作品 の資料より。これら景観化にまつわる作品についての考察は別の機会に 行われるであろう。

\section{図版出典と補足}

Fig.1『JEXPO'70 会場計画』の図面「19 全体配置」と図面「18 土地利 用」と図面「20 主要諸施設と恒久施設及び仮設施設」図面「26 敷地内土 地利用」図面「16 交通ネットワークと展示エリア」より筆者作成。 Fig.2 図面「A25 全体配置計画のヴァリエーション」、『JEXPO'70 会場計 画』

Fig.3 Fig.2 と同様

Fig.4 Fig.3 より筆者作成。なお [] 内の語句は筆者が加筆したものであり、 原図には無い。他の図でも同様。

Fig.5 Fig.2 と同様

Fig. 6 Fig.5 より筆者作成

Fig.7 Fig. 2 と同様

Fig.8 Fig.7 より筆者作成

Fig.9 Fig.2 と同様

Fig.10 Fig.9 より筆者作成

Fig. 111 は「万博計画 $[\mathrm{I}] 」$ 、p.51 の図に、p.52 の A 図および B 図からの情 報を加筆して筆者作成。2 は「スイス博覧会 ローザンヌ」(『国際建築』1964 年 10 月号）の「配置案内図」、p. 27 より筆者作成

Fig.12「万博計画 $[\mathrm{I}] 」$ 、p.54の図に凡例を加筆して筆者作成。イール・ヴ エルト内の区分は、『近代建築』1966 年 1 月号、 $\mathrm{p} 43$ に掲載のモントリオー ル博のマスター・プランによる。

Fig.13「万博計画 $[\mathrm{I}]\rfloor$ 、p.56 の図に加筆して筆者作成。大きな展示館は会 場の端にあり、テーマ館は中心にある。

Fig.14 Fig.12 および Fig.1-1 より筆者作成 


\section{Hikaru MOMMA ${ }^{* 1}$ and Takahiro TAJI*2}

${ }^{11}$ Doctoral Candidate, Graduate School of Engineering, Kyoto University, M.Eng.
${ }^{2}$ Prof., Graduate School of Engineering, Kyoto University, Dr.Eng.

Banpaku-keikaku is the master plan of Expo'70 designed by Tomoya Masuda \& associates. Banpaku-keikaku has following characteristics: 1) Exhibition areas and artificial lake are designed to make a total view of the site. 2)Manipulation of the topography is related to placement of exhibition areas. 3)Viewing of the Expo starts with getting a total view of the site by the transportation. 4)With these elements, Banpaku-keiakaku was designed to achieve an idea called Keikan-ka, which is making a new landscape that has a new meaning. 5)Banpaku-keikaku were designed based on usage of former site. This work is important because concepts of discernment and manipulation of the topography and Keikan-ka which are related to Masuda's thoughts are utilized. Therefore, the author has studied its ideas and characteristics on the preceding paper (2019). Based on that paper, the author aimed to reveal how they developed that ideas and characteristics on this paper. There are two important materials for this aim which are made before completion of Banpaku-keikaku. That are four drafts for Banpaku-keikaku, and examination of the two past exposition, which are Lausanne Expo'64 and Montreal Expo'67 by Tomoya Masuda \& associates. The former are included in a unpublished blueprint book 『JEXPO’70 会場計画』,which is discovered by the author, the latter are included in 「万博計画 $[\mathrm{I}] 」$, which is a published articles of Banpaku-keikaku. The author studied these materials. In chapter 2 , the author re-draw and analyzed four drafts, which are drawn by Kunio KATO, Shigeyuki OKAZAKI, Go SHIRAI, and Takashi TANAKA. And we found following 2 points. 1)Banpaku-keikaku may be based on KATO's draft. This is because KATO's draft has many points of similarity to Banpaku-keikaku, in particular only KATO's draft shows usage of former site.2) Making a total view of the site are not aimed on any drafts so that Keikan-Ka do not exists at the preliminary design of Banpaku-keikaku.3) Concepts such as discernment and manipulation of the topography, and regarding usage of former site as important are not aimed on all drafts. Accordingly, these ideas do not exist at the preliminary design of Banpaku-keikaku.

In chapter 3, the author analyzed Masuda \& Associate's examination of two past exposition and found following 3 points. 1)They found the defect of Lausanne Expo that is there are no areas to synthesize the expo. Masuda's plan was designed after solving that defect. 2)They found that Montreal Expo is designed after utilizing the existing topography such as Saint-Lawrence River and the island and pier of the site. Masuda's plan was designed after developing that way to achieve Keikan-ka with artificial lake and placement of the exhibition areas. 3)They examined Montreal Expo from the perspective of reading the topography.

Conclusions are as follows. 1)Discernment and manipulation of the topography does not exist in the four drafts. But Masuda \& associates examined the Montreal exposition from the perspective of reading the topography. 2)The four drafts were not designed to realize an idea called Keikan-ka. And the two past expositions did not examined from the perspective of whether the expositions were designed to make the site seen as one united area like Banpaku-keikaku was. 3)Characteristics of Banpaku-Keikaku took shape after drawing the four drafts. 